\title{
Properties of pronominal subjects
}

\author{
Posio, Pekka Johannes
}

Cambridge University Press

2018

Posio , P J 2018 , Properties of pronominal subjects . in K Geeslin (ed.), The Cambridge Handbook of Spanish Linguistics. Cambridge Handbooks in Language and Linguistics, Cambridge University Press , Cambridge , pp. 286-306 . https://doi.org/10.1017/9781316779194.014

http://hdl.handle.net/10138/309946

https://doi.org/10.1017/9781316779194.014

unspecified

acceptedVersion

Downloaded from Helda, University of Helsinki institutional repository.

This is an electronic reprint of the original article.

This reprint may differ from the original in pagination and typographic detail.

Please cite the original version. 


\section{Properties of Pronominal Subjects}

Pekka Posio, University of Stockholm

Keywords: subjects; pronouns; person; syntax; semantics; pragmatics; sociolinguistics; typology; information structure

Abstract: The expression and omission of subject personal pronouns - often exemplified by the contrast between canto and yo canto, both meaning 'I sing' - is one of the most widely studied features of Spanish syntax. The phenomenon has been tackled from various theoretical and empirical perspectives and using diverse terminology ranging from "pro-drop" in the generative framework to "variable subject expression" in functionally oriented studies. Traditional grammar considers the omission of subject pronouns as the norm and refers to the intuitive notions of contrast and emphasis to account for cases where they are used. However, genuinely contrastive uses of pronominal subjects are rare in practice and the choice between expressing the subject person only by means of bound person marking on the verb (canto) or by both independent subject pronoun and bound person marking (yo canto) is affected by several other factors. While there is extensive evidence that grammatical person and coreferentiality with the previous subject or lack thereof affect subject pronoun expression in all varieties of Spanish, the frequency of expressed subject pronouns differs across dialects. Caribbean Spanish is characterized by high frequency of expressed subject pronouns whereas Mexican and Peninsular varieties display lower rates of subject pronoun expression. Psycholinguistic phenomena like priming of previously used or heard sequences or entrenchment of frequently repeated verb-subject combinations have also been shown to play a crucial role in explaining variable subject expression in spoken discourse. The current chapter sets out by defining the scope of variation in the expression of pronominal subjects and by situating Spanish in a typological perspective with regard to other languages. Next, an overview is provided of the different types of factors that have been found to affect the phenomenon. Finally, we summarize what is known of Spanish subject expression at present and discuss possible directions for future research. 


\section{Introduction: variable expression of pronominal subjects}

The variable use of subject personal pronouns is among the most widely studied features of Spanish syntax. Pronominal subjects can be expressed by a subject pronoun placed before the verb (example 1a), after the verb (1b) or left unexpressed (1c).

1a. Y yo creo que eso es sano.

'And I think that it is healthy.'

b. No creo yo que mañana tengamos reunión.

'I don't think that we have meeting tomorrow.'

c. Pues creo que no lo sabía.

'Well I think that he didn’t know it.' (CREA)

This property distinguishes Spanish from English and some other Western European languages like German and French that have obligatory pronominal subjects. Languages resembling Spanish are frequently referred to as null subject or pro-drop languages. Both terms originate in the Principles and Parameters version of Generative Grammar (see Chapter 1) where the term pro-drop is used of a cluster of syntactic properties including null subjects and "free" constituent order (Chomsky 1981). These terms are widely used in linguistics, although conceptualizing the lack of independent subject personal pronouns as "dropping” or as "null” arguments has also been criticized as linguistic Anglo-centrism (Dryer 2011). In more functionally oriented studies, the term "variable subject expression” has been used instead to better account for the complex nature of the phenomenon (see e.g. Otheguy and Zentella 2012; Travis and Torres Cacoullos 2012; Carvalho, Orozco and Shin 2015).

Spanish subject pronoun expression is a textbook example of variable syntax, and exploring what factors condition subject pronoun expression has become a popular topic in studies using variationist sociolinguistic methodology. The first task in variationist studies is to determine the envelope of variation, i.e. the contexts where variation may occur. For example, syntactically impersonal verbs such as meteorological verbs (e.g. llueve 'it rains') and existential verbs (e.g. hay 'there is/are') are excluded from the envelope of variation, as they do not admit pronominal subjects, with the exception of Dominican Spanish where the neuter personal pronoun ello may be 
used as an expletive subject (Toribio 2000). Another restriction in the use of subject personal pronouns concerns the animacy of the referent: personal pronouns are seldom used for non-human referents in most varieties of Spanish, and thus only noun phrases or null subjects are used to refer to them (however, see Elinzaincín 1995; Bullock and Toribio 2007:56 for Uruguayan and Dominican varieties, where subject personal pronouns can be used for non-human referents). On the other hand, there are also non-variable contexts where subjects must be expressed, e.g. if they carry focal information as when answering the question 'who did it?' (see Section 3.1), when they are heads of relative clauses, or when they have adverbial modifiers (e.g. solo yo 'only me'). Unlike subject personal pronouns, indefinite and interrogative pronouns (e.g. alguien 'someone', quién 'who') are generally not omissible. Apart from the generally recognized non-variable contexts, authors of different studies may decide to include or exclude e.g. imperatives and formulaic sequences (such as tú sabes 'you know’; see Section 3.5), depending on how variable subject pronoun expression is in those contexts in the variety being studied.

Table 1 summarizes the types of subject expression found in most standard varieties of Spanish, showing what forms of subject expression are possible depending on the grammatical person ${ }^{1}$ and the type of subject referent (human, non-human, non-referential).

Table 1. Variation in subject expression

\begin{tabular}{|l|l|l|l|}
\hline & +human referent & -human referent & $\begin{array}{l}\text { non-referential or } \\
\text { expletive subject }\end{array}$ \\
\hline $\begin{array}{l}\mathbf{1}^{\text {st }} \text { and } 2^{\text {nd }} \text { person } \\
\text { singular and plural }\end{array}$ & pronoun / null & n/a & n/a \\
\hline $\begin{array}{l}3^{\text {rd }} \text { person singular } \\
\text { and plural }\end{array}$ & $\mathrm{NP} /$ pronoun / null & $\mathrm{NP} /$ null & null \\
\hline
\end{tabular}

Most corpus-based studies examine only contexts that fall within the envelope of variation, as explained above. It is therefore important to note that non-variable contexts may actually account

\footnotetext{
${ }^{1}$ The term "grammatical person" is used throughout the chapter to refer to the six combinations of person (1st, 2nd, 3rd) and number (singular vs. plural) features found in Spanish. For the purposes of the present chapter, it is not meaningful to separate these two features since they always co-occur in Spanish and because all grammatical persons have unique discourse functions. For example, first person singular is frequently used with mental predicates expressing the speaker's cognitive or epistemic stance, but the same is not true of first person plural; third person plural, unlike third person singular, can be used for vague or indefinite reference; second person singular, unlike first person singular, is frequently used in interrogative sentences.
} 
for a large proportion of data, in particular if all grammatical persons are included. For example, in Peškova’s (2015:140) data from Buenos Aires Spanish, 55\% of the subjects are obligatorily null, and $3 \%$ are obligatorily expressed. Thus, only the remaining $42 \%$ of clauses constitute the envelope of variation.

Even if the overall rates of expressed subject pronouns within the envelope of variation differ across dialects, studies show that factors affecting subject expression are essentially the same in all varieties of Spanish. The internal ranking of the significant factor groups is also very similar, although dialectal differences occur. Thus, it can be generalized very broadly that subject personal pronouns are expressed more often in singular than in plural persons, when there is a change in reference with regard to the previous subject, and when the verb is in an imperfective tense as opposed to a perfective one (e.g. Silva-Corvalán 1982; Enríquez 1984; Bentivoglio 1987; Cameron 1992, 1994, 1995; Travis 2007; Torres Cacoullos and Travis 2011; Otheguy and Zentella 2012). Since several factors affect subject expression simultaneously and in interaction with each other, most data-based studies use logistic regression (often by means of the program VARBRUL or GoldVarb) or other statistical modeling in order to check for the significance of each factor, their internal ranking and interactions between the factors.

The present chapter sets out by looking at Spanish subject expression in a language typological perspective in Section 2. Section 3 focuses on linguistic factors and Section 4 on the extralinguistic factors of subject expression variation. Section 5 deals with written language and the diachrony of subject expression and Section 6 on postverbal placement of pronominal subjects. Some concluding remarks and future research directions are summarized in Section 7.

\section{Spanish in a language typological perspective}

Comparisons between languages like English and Spanish suggest that a language can do without overt subject personal pronouns as long as the subject person is marked on the verb, as is the case in Spanish. However, examining a wider sample of languages reveals that the connection between bound person marking on the verb and null subjects is not universal. There are languages with obligatory double marking of the subject, i.e. requiring bound markers on the verb as well as the use of independent subject pronouns, like German; there are also languages with no person marking on the verb that nevertheless allow null subjects, as is the case in many East-Asian languages. 
In a typological perspective, Spanish belongs to the most common language type where the subject person is normally expressed by affixes on the verb, whereas languages like English with obligatory subject pronoun expression are a minority. While the use of subject personal pronouns is variable in Spanish, the expression of subject person on the verb is not: all finite verbs are obligatorily marked for grammatical person. In Dryer’s (2011) typological sample of 711 languages, 437 (i.e. 62\%) are similar to Spanish whereas only 82 (i.e. 12\%) are like English with regard to the expression of pronominal subjects. Other subject marking patterns found in the world's languages include having no marking on the verb and optional use of independent subject pronouns, or using different subject marking strategies depending on the grammatical person or verbal tense. These two types are referred to as "radical” or “discourse pro-drop” and "partial pro-drop”, respectively, in the formalist terminology (Roberts and Holmberg 2010).

Although both formal and typological classifications of languages with regard to their subject expression properties have been developed, there have been only few attempts to compare actual rates of subject expression in different languages (however, see Seo 2001 for Slavic languages). Languages and language varieties having the same grammatical possibilities of subject expression may actually represent very divergent patterns in actual usage. It has nevertheless been suggested that referential continuity and priming are likely candidates for cross-linguistic constraints on subject expression (Torres Cacoullos and Travis 2016:743).

\section{Linguistic factors affecting subject pronoun expression}

\subsection{Traditional explanations: contrast and emphasis}

In traditional, normative grammar of Spanish, pronominal subject use is considered a way to express contrast, emphasis or individuation of the subject person or as a means to disambiguate morphologically ambiguous person marking (e.g. Gili y Gaya 1964). Similar explanations are found in learners' grammars and textbooks of Spanish as well as in reference grammars (e.g. Fernández Soriano 1999). Butt and Benjamin (2004) give the sentences in (2) to illustrate contrastive and emphatic uses of subject pronouns.

2. a. Tú eres listo, pero ella es genial. 
'You're clever but she's a genius.'

b. Tú haz lo que te dé la gana.

'You do whatever you like (implies ‘what do I care?’).' (Butt and Benjamin 2004:131)

Although the notions of contrast and emphasis may seem intuitively attractive, they have little explanatory power when considering subject pronoun use in actual discourse. Genuinely contrastive contexts are infrequent in authentic spoken data, so that contrasting the subject referent with other potential referents only accounts for a fraction of expressed subject pronouns (Travis and Torres Cacoullos 2012:723) and not all contrastive contexts require expressed subject pronouns (Matos Amaral and Schwenter 2005). In addition, attributing subject pronoun presence to an emphasizing function is circular in the sense that it is difficult to provide an independent definition of emphasis, i.e. a definition that does not rely on the presence of the subject: since an unexpressed subject pronoun cannot be emphasized, all expressed subject pronouns can be claimed to be emphatic due to being expressed.

\subsection{Structural factors: verb morphology and grammatical person}

Alongside contrast and emphasis, traditional grammar maintains that subject pronouns are used to avoid ambiguity in those tenses and moods where first and third person singular have the same form. This occurs in the Imperfect of Indicative (cantaba 'I/he/she/it sang'), Conditional (cantaría 'I/he/she/it would sing'), Present and Imperfect of Subjunctive (cante, cantara/cantase 'I/he/she/it sing[s]') and compound tenses containing these forms. In addition, in dialects where postnuclear /s/ is omitted, second person singular forms may be pronounced similarly to first and third person, thus creating a further syncretism between all singular persons. Thus, it would seem well motivated to use subject pronouns with syncretic verb forms in order to disambiguate the grammatical person, as in example (3) where not expressing the pronoun yo could cause a coreferential interpretation of the subject referent of the verbs as the verb form estaba can refer to both first and third person singular.

\section{Y ella iba a mi lado y yo estaba temblando [...]}

'And she was walking by my side and I was shaking [...]' (Silva-Corvalán 2001:155)

Functional compensation for lacking or impoverished person marking morphology has been suggested to account for obligatory subject pronoun expression in French, formerly a null-subject 
language with distinctive person marking on the verb (however, see Ranson 2009) and for the increasing use of subject pronouns in Brazilian Portuguese (Duarte 2000). Although some studies have found evidence in favor of the functional compensation hypothesis in Spanish (Hochberg 1986), it has not been supported by other studies with different data (Ranson 1991; Cameron 1992, 1994). While subject pronoun expression may be a way to avoid potential referential ambiguity, immediate discourse context and referential continuity often disambiguate the reference in the absence of expressed subject pronouns. In addition, the fact that subject pronouns are also frequently used in tenses and moods with no ambiguous person marking, such as the present of indicative, suggests that functional compensation is not among the main functions of subject pronoun expression.

Other structural factor groups that have been studied in connection to subject pronoun expression are clause type, verb type and grammatical person. It has been found that pronominal subjects are expressed more often in main clauses than in dependent clauses, and least often in coordinate clauses (e.g. Enríquez 1984:256-258; Orozco and Guy 2008:77), although other studies have found no such effect (e.g. Torres Cacoullos and Travis 2011:254). In addition, reflexive verbs tend to have lower rates of expressed subject pronouns than non-reflexive ones (e.g. Otheguy and Zentella 2012:187).

One of the most significant factor groups is grammatical person. Pronominal subjects are most frequently used in the singular and least frequent in the plural persons. For example, in Otheguy, Zentella and Livert (2007), grammatical person is chosen as the single most important factor group in accounting for subject pronoun use. Since the deictic speech act persons and the anaphoric third person are also functionally very different, researchers often focus on only one grammatical person at a time (e.g. Travis and Torres Cacoullos 2012) or analyze each grammatical person separately (e.g. Geeslin and Gudmestad 2016).

Perhaps the most striking difference is found between first person singular and plural whose expression rates in Peninsular Spanish data can be as far from each other as $34.6 \%$ and $4.5 \%$, respectively (Posio 2012:346). High expression rates of the first person singular pronoun yo have been attributed to the egocentric nature of communication (Davidson 1996:553). This does not necessarily mean that people often tend to talk about themselves: rather, a great deal of first person singular verb forms in discourse are tokens of mental or communicative verbs whose function is to 
express the speaker's subjective stance, and such verbs may have subject expression patterns that diverge from general tendencies (see Section 3.6).

\subsection{Referential continuity: same and switch reference}

Continuity of reference is another highly significant predictor of subject pronoun expression. Subjects that are coreferential with the previous subject (or another entity, such as a direct object) are less likely to be expressed by pronouns than subjects that are not coreferential with the previous subject (Cameron 1992, 1994, 1995, 1997). The terms "same reference” and "switch reference" are often used instead of coreferential and not coreferential. This effect derives from a more general principle of information structure (see Chapter 17): the less accessible a referent is to the addressee, the more distinctive coding is used to refer to it (Givón 1983, Ariel 1994).

An example of switch reference is given in (4) where the pronominal subject usted 'you' and the following nosotros 'us' refer to different entities and thus trigger the expression of subject pronouns (irrespectively of whether the speaker intentionally wishes to contrast or emphasize these persons).

(4) 5s: Y es la única casa que no tiene luz.

A: Si si an- ¿anoche el teléfono que usted me dio?

5s: uhhuh

A: De esa casa nosotros la llamamos.

'5s: And it's the only house that has no electricity.

A: Yes yes, las- last night the number that you gave me?

5s: uhhuh

A: From that house we called it.' (Notiuno 1320 AM: San Juan)

(Cameron 1994:314)

Travis and Torres Cacoullos (2012) propose a more elaborate account of switch reference effects by looking at the number of intervening semantically compatible human subjects between two mentions of the same subject referent in discourse (see example 5 below). Their findings suggest that intervening human subjects provide a better explanation of variable subject expression in first person singular than switch reference as such (Travis and Torres Cacoullos 2012:728). 


\subsection{Psycholinguistic phenomena: priming and frequency effects}

Subject expression has been shown to be affected by psycholinguistic phenomena related with the speakers' short-term and long-term memory. Several studies have confirmed the existence of a priming or perseverance effect (e.g. Cameron 1992; Cameron and Flores-Ferrán 2004:50-54; Torres Cacoullos and Travis 2011:251-252, 2012; Travis 2007:120-121). Simply put, priming effect accounts for the finding that subject pronouns are more likely to be used when the previous subject has been expressed by a pronoun, whereas null subjects are more likely to be used when the previous subject has been null. Priming is considered as a mechanical and unintentional effect rather than serving any pragmatic purposes (Bock and Griffin 2000:177). Example (5) illustrates a possible priming effect between (a) two coreferential expressed subject pronouns and (b) two coreferential null subjects. $^{2}$

(5) a. Yo no tenía máquina de lavar. Yo lavaba con lavadero.

'I didn’t have a washing machine. I washed with a washboard.” [05 Las tortillas, 0:02:39-0:02:42]

b. ya Ø no quería. ... it was too hard. ... (1.5) pero Ø lo hice.

“(I) didn’t want to any more. ... it was too hard. ... (1.5) but (I) did it.” [04 Piedras y gallinas, 12:54:44-12:54:46] (Torres Cacoullos and Travis 2016:739).

Another psycholinguistic effect targeting the speakers' long-term rather than short-term memory has been argued to account for lexical differences found between different verb forms. Erker and Guy (2012) found that while lexical frequency of verb forms (i.e. the rate at which they occur in speech) did not condition subject expression on its own in their data, it had an amplifying effect on the significant factor groups affecting subject expression in their study (morphological regularity, semantic class, and person). These factors groups significantly predicted pronoun usage among the most frequent lexical items (e.g. creo 'I think', $v a$ 'he/she/it goes') but not for the less frequent ones (e.g. crezca 'grow-1/3sG.SUBJUNCTIVE'). Erker and Guy (2012) argue that patterns of subject expression are more entrenched with the frequently occurring verb forms than with the less frequent

\footnotetext{
${ }^{2}$ Note that in (5b) there is an intervening subject it in the code-switching sequence it was too hard; however, since this is not a human subject it does not trigger the use of a subject pronoun with the following verb (Travis and Torres Cacoullos 2012).
} 
ones. However, other studies provide conflicting evidence on the effect of frequency. In Bayley, Holland and Ware's (2013) data, frequency did not have an amplifying effect on the other factor groups, but instead infrequent verbs slightly favored subject expression. Linford et al. (2016a), in their study focusing on third person verb forms and including null, pronominal, and noun phrase subjects, found neither independent nor mediating effect of lexical frequency on subject expression similar to Erker and Guy's results (2012). However, they did find that frequency mediates the effect of specificity of reference in the third person, although in different ways for native vs. non-native speakers (Linford et al. 2016a).

In sum, there is contrastive evidence on the effect of lexical frequency of verbs on subject expression. Linford et al. (2016a:210) suggest that the discrepant results between different studies may be due to what grammatical persons are analyzed and how the envelope of variation is defined. The choice of grammatical persons and whether they are analyzed separately or merged together, as well as the decision to include or exclude tokens susceptible of being formulaic sequences in a given variety (such as tú sabes 'you know', excluded by Bayley et al. 2013 but included by Erker and Guy 2011) may have strong influence on the results and renders comparisons between individual studies difficult.

\subsection{Semantic and pragmatic factors, and formulaic patterns of subject expression}

Verb semantics has been found to be connected to subject expression, although the mechanism connecting different verb lexemes - or different tokes of verbs - with different subject expression patterns are not always clear. Several studies have found a connection between higher subject expression rates and verbs expressing mental or cognitive processes such as creer 'believe' and pensar 'think’ (among many others, Enríquez 1984; Bentivoglio 1987; Morales 1997; Hurtado 2005; Posio 2011) and some studies also report a lower rate of expressed subjects with verbs of external activity (e.g. Enríquez 1984; Morales 1997). It should also be noted that verb semantics and grammatical person are tightly interrelated: for example, mental verbs favoring subject expression are most frequently used in first person singular.

Several explanations have been proposed to account for the observed differences. For example, Enríquez (1984:244-245) argues that subject pronouns are most frequently used with those verbs that express subjective or interior activities where the speaker has a need to individuate the subject 
more than with verbs expressing external actions. Silva-Corvalán (1997:127) proposes that not expressing the subject may serve the purpose of focusing more attention on the action expressed by the verb, which would account for more frequent subject expression in imperfective tenses rather than in perfective tenses that refer to foregrounded actions. A similar principle of attention focusing could account for the differences between verb classes (Posio 2011). However, definitions of verbal categories and what verbs are included in each category vary considerably from one study to another, making comparisons across studies difficult.

What seems to be a category effect may actually be caused by few frequently occurring members within a category. Thus many of the most frequently occurring verb forms within the category of cognitive verbs serve different pragmatic functions such as expressing the speaker's epistemic stance (e.g. creo '[I] think’, no sé ‘[I] don’t know') and such sequences may be associated with subject expression patterns differing from the general trends (Posio 2015; see also Linford et al. 2016b:150). Token-specific tendencies of subject expression may vary across dialects, suggesting that such tendencies are community-based usage patterns rather than tendencies derived directly from verb semantics. For example, in Orozco's (2015) data from Colombian Spanish, the verb form sé ‘(I) know’ favors subject expression while in Posio’s (2015) data from Peninsular Spanish, it favors null subjects.

Within the category of cognitive verbs, the verb form creo 'I think' is so frequently used in spoken Spanish that it accounts for $15 \%$ of all occurrences of first person singular verb forms in the Corpus del Español (Posio 2014:8). Since the rate of expressed subjects in the sequence creo que 'I think that' can be as high as 62\% (Posio 2015:64), this sequence boosts the frequency of subject pronoun use in first person singular and in the category of mental verbs. In fact, sequences containing creo are grammaticalizing into epistemic markers similar to English I think (Thompson and Mulac 1991) and therefore should be analyzed separately from more productive verbs.

As for the pragmatic functions of pronominal subjects in discourse, it has been proposed by Davidson (1996) that they have the general function of adding "pragmatic weight" to an utterance. This notion is intended to subsume different functions ranging from triggering speech act or epistemic readings of communication and mental verbs to taking or handing over the floor in a conversation. However, it is debatable whether such a unitary function can account for all pragmatic uses of subject pronouns with verbs and to what extent pragmatic usage patterns differ between speaker communities or dialects. Another pragmatic account is proposed by Serrano and 
Aijón Oliva (2011) who argue that the expression of the subject pronoun in either preverbal or postverbal position and its omission represent different construals of subjectivity versus objectivity of the speaker as well as different grades of prominence vs. informativity of the subject referent in discourse.

\section{Extralinguistic factors affecting subject pronoun expression}

\subsection{Sociolinguistic factors}

Although subject expression has been widely studied using quantitative sociolinguistic methodology, there is only scattered and partially contradictory evidence on the influence of social variables such as age, gender, profession or level of education of the speakers on their subject expression tendencies. For example Otheguy, Zentella and Livert (2007:778) in their study on Spanish spoken in New York City found that neither gender, age, education, socioeconomic status nor class had a significant effect on the rates of subject pronoun expression. However, other studies have reported that older speakers produce higher rates of expressed subject pronouns than younger speakers (e.g. Orozco and Guy 2008 for Barranquilla, Colombia; Alfaraz 2015 for Santo Domingo, Dominican Republic; Lastra and Butragueño 2015 for Mexico City; Orozco 2015 for Costeño Colombian Spanish; de Prada Pérez 2015 for Catalan-Spanish bilinguals in Minorca, Spain). It is unclear whether the age-related pattern instantiates language change or age grading. Diachronic evidence from other Romance languages shows that subject pronoun expression tends to increase rather than decrease over time (see Section 5). If this is true for Spanish, the increasing frequency of subject pronoun use may be attributable to age grading rather than to ongoing changes.

Speaker gender has also been shown to have a significant effect in some studies, with females slightly favoring subject expression (e.g. Alfaraz 2015:10, Orozco 2015:30). Shin and Otheguy (2013) observe that women lead the ongoing change in the increasing use of subject pronouns in a contact situation between Spanish and English. There is also some evidence to the effect that speakers' age and gender correlate with the choice of grammatical subjects in discourse (Posio 2016) which in turn may have implications on the rates of expressed subject pronouns per speaker. However, in general age and gender differences are not among the most significant factor groups accounting for subject pronoun use. 


\subsection{Dialectal differences}

The rates of expressed subject pronouns in speech are subject to extensive dialectal variation. The highest frequencies of expressed subject pronouns are found in Caribbean Spanish (e.g. Orozco and Guy 2008; Otheguy and Zentella 2012). In particular, Dominican Spanish shows general expression rates as high as 51\% (Martínez-Sanz 2011) or even 96\% in the case of second person singular (Alba 2004). The lowest rates have been observed in Mexico: according to Lastra and Butragueño (2015:42), the general rate of expressed subjects in Mexico City Spanish is $21.7 \%$ while Michnowicz (2015:109) reports a frequency as low as 16.0\% for monolingual speakers of Yucatan Spanish. Despite dialectal differences in subject expression rates, so far all studies point at the same probabilistic constraints on subject expression across dialects and discourse types (Cameron 1992, 1994; Travis 2007; Torres Cacoullos and Travis 2016).

It is not completely clear why different Spanish dialects present different rates of subject expression. One of the explanations that have been proposed is that dialects where syllable-final /s/ is frequently deleted would compensate the loss of distinctions in person marking by means of increased subject pronoun use (e.g. Hochberg 1986). However, this functional compensation effect is not systematic and thus does not account for all dialectal differences (see Section 3.2 above). Interestingly, subject expression rates and the proportion of postverbal subjects (see Section 6 below) in a dialect seem to correlate negatively with each other (Morales 1989; Cameron 1992; Toribio 2000). This is the case especially in Caribbean Spanish where subject pronouns are very frequently expressed and they are frequently preverbal even in contexts that would require postverbal placement in other dialects (see example 6).

6. ¿Qué tú piensas? (acceptable in Caribbean Spanish but not in other varieties) vs. ¿Qué piensas tú? (acceptable in all varieties)

'What do you think?' (Morales 1989)

The positive correlation between expressed subjects and the prevalence of the subject-verb order may offer evidence in favor of the clustering of null subjects and "free" constituent order within a single paradigm, as proposed in Generative Grammar (Chomsky 1981). 
A special case of subject pronoun expression where dialects of Spanish differ considerably from each other are the non-specific, generic or impersonal uses of the second person singular, illustrated by example 7 (e.g. Cameron 1994; DeMello 2000; Otheguy, Zentella and Livert 2007; Kluge 2010; Guirado 2011).

7. Es difícil entenderles, muchas veces tú hablas con un costeño y no le entiendes ni una palabra. (BOG-27)

'It's difficult to understand them, often you speak with a Costeño and you don't understand a single word.' (DeMello 2000:361)

Dialects of Spanish vary regarding the proportion of the impersonal second person singular vs. other impersonalization strategies like the pronoun uno 'one', possibly depending on the frequency of the second person singular as an address form in the dialect (Guirado 2011). In those dialects where the second person singular is used as an impersonalization strategy, the pronoun expression rate may be significantly higher or lower than when the form is used for personal reference, as shown in Table 2 for Puerto Rican and Peninsular Spanish data.

Table 2 Type of reference and subject expression in second person singular (Cameron 1994:325)

\begin{tabular}{|l|ll|ll|}
\hline & \multicolumn{2}{|l|}{ San Juan } & Madrid & \\
\hline Personal & $48 \%$ & $(\mathrm{~N}=145)$ & $40 \%$ & $(\mathrm{~N}=58)$ \\
\hline Impersonal & $69 \%$ & $(\mathrm{~N}=188)$ & $19 \%$ & $(\mathrm{~N}=150)$ \\
\hline
\end{tabular}

DeMello (2000:369) proposes that the differences observed by Cameron (1994) could be attributed to general differences between syntactically innovative and syntactically conservative dialects. However, the connection between innovativeness and pronoun use is far from clear. Interestingly, Geeslin and Gudmestad (2016:70) note that subject expression tendencies of native speakers are sensitive to impersonality vs. specificity of reference whereas non-native speakers are not. This finding provides further evidence that subject expression in generic second person singular is a dialect-specific feature acquired late by second language learners. 


\subsection{Language contact}

Since subject personal pronouns have essentially the same meaning in different languages, they offer a convenient point of comparison for testing hypotheses of language change due to contact situations. The most extensively studied contact situation is that between Spanish and English in the United States (for recent studies on contact situation with other languages, see Carvalho, Orozco and Shin [2015]). The hypothesis that contact with English, a language with nearly obligatory subject pronoun expression, would increase rates of expressed subject pronouns in Spanish was put forward already by Granda Gutiérrez (1972) and it has been studied, among many others, by Bayley and Pease-Álvarez (1996), Lipski (1996), Lapidus and Otheguy (2005) and Otheguy and Zentella (2012).

Not all studies have found evidence for a decisive effect of contact with English (e.g. Flores-Ferrán 2004; Travis 2007). Otheguy, Zentella and Livert (2007:786), who do observe a contact effect in New York Spanish, consider that the contradictory findings may be due to differences in sample size and coding. Otheguy, Zentella and Livert’s (2007) data from New York Spanish speakers, consisting of 142 interviews and 63,500 finite clauses, provides robust evidence that speakers born in or brought to New York City before three years of age produce a significantly higher rate of expressed subject pronouns than newcomers, i.e. speakers who had come to New York City at age 17 or older and spent there less than five years. However, the study also shows that contact with speakers of other varieties of Spanish levels the differences between speakers of Mainland and Caribbean dialects in terms of constraint hierarchies for the factor group grammatical person. In practice, speakers of Mainland dialects accommodate their use of subject pronouns in different grammatical persons more towards the usage of the Caribbean dialects (Otheguy, Zentella and Livert 2007: 794; Otheguy and Zentella 2012:218).

The influence of language contact has also been studied with a special focus on code-switching contexts. Again, the language pair that has received most attention is Spanish and English. The presence of code-switching with English can be assumed to boost the rates of expressed subject pronouns, given that subject pronouns are nearly obligatory in English. However, Torres Cacoullos and Travis (2011) observe no differences in subject expression between contexts with and without code-switching in New Mexican data. They nevertheless find that although code-switching has no intrinsic effect on subject expression, it does have an influence on the priming effect for expressed subjects, given that presence of English means more expressed subject pronouns. 


\subsection{Language acquisition in first and second language Spanish}

Subject expression provides an interesting phenomenon for studies on language acquisition, as it allows examining differences in the probabilistic grammar of children compared to adults and determining the developmental stages at which the variability is acquired. In general, children tend to produce less pronominal subjects than adults (Shin and Erker 2015; Montrul and Sánchez-Walker 2015). In Shin and Erker's (2015) data, the subject expression rate of adult speakers of Mexican Spanish is 21\% while children between 6 and 8 years of age have a pronoun expression rate of only 9\%. Nevertheless, the predictors of subject pronoun expression and their internal hierarchy are essentially the same for both children and adults. Geeslin, Linford and Fafulas (2015:204) find that second-language learners of Spanish with highest and lowest proficiency levels selected similar rates of expressed subject pronouns as native speakers in a task while intermediate-level students selected higher rates. However, only the advanced-level students were sensitive to the same linguistic predictors as the native speakers.

\section{Diachrony of subject expression}

Although variable subject expression is found in both spoken and written language, the majority of research has focused on spoken data: variation in the use of pronominal subjects in texts remains less explored. Similarly, the great majority of studies have focused on synchronic data. Spanish and other Romance languages inherited variable subject expression from Latin. Unlike French, where the expression of subject pronouns has become obligatory and Brazilian Portuguese, where there is evidence of a similar development (Duarte 2000), Spanish and most other Romance languages seem to have conserved the variability present in Latin. However, little is known of the diachrony of subject expression in Spanish.

In one of the few studies on the history of subject pronoun usage, Ramos (2016) finds both similarities and differences between literary texts from the $14^{\text {th }}, 15^{\text {th }}$ and $16^{\text {th }}$ century and presentday spoken Spanish. Although overall rates of expressed subject pronouns are lower in the historical corpora than in present-day data, discontinuity of reference and imperfect tense favor subject expression similarly to modern-day spoken Spanish. Differently from present-day spoken data, the semantic class of the verb has no significant effect in the diachronic corpus. In particular, 
the tokens creo 'I think' and sé 'I know' are rather infrequent and show no distinct patterns of subject expression (Ramos 2016:120). While these findings may suggest that the development of verb-specific patterns is a recent phenomenon, it is reasonable to ask to what extent literary texts, even those representing dialogue, are comparable with spoken data. There is no reason why literary dialogue or prose should faithfully simulate the tendencies found in spoken discourse. In particular, frequently occurring discourse formulae may be used sparingly in literary dialogues, resulting in divergent rates of subject expression in comparison to spontaneous speech.

\section{Postverbal position of pronominal subjects}

Despite the extensive literature on constituent order and its relation with information structure (see Chapter 17), few studies have focused specifically on the position of pronominal subjects with regard to the verb (however, see Serrano and Aijón Oliva 2010, Posio 2012, Aijón Oliva and Serrano 2012, Serrano 2013).

As a broad generalization, noun phrases (NPs) representing new information are introduced into discourse in the postverbal position, whatever their syntactic function is. This also concerns NP subjects. However, since subject personal pronouns by default refer to known entities (the speaker, the addressee or other human referents accessible to the addressee), postverbal placement seems to serve different functions for pronominal subjects than it does for NP subjects. It is also considerably less common for pronouns than for NPs to be placed postverbally: while 18-40\% of all NP subjects in Spanish are postverbal (Meyer-Hermann 1990), much lower percentages have been reported for subject pronouns, ranging from 1.5\% in Spanish spoken in New York City (Otheguy, Zentella and Livert 2007:771) to 13.2-17.4\% in Peninsular Spanish (Serrano and Aijón Oliva 2010).

While preverbal subject pronouns may be separated from the verb by several intervening words, there is a strong tendency for postverbal subject pronouns to occur immediately adjacent to the verb (Posio 2012:155). At least in Peninsular Spanish, the postverbal position is most typically associated with verbs of speech or cognition in formulaic sequences (digo yo 'I say', creo yo 'I think'), some imperatives with formulaic meanings (fíjate tú 'oh, wow', literally 'pay attention') and contexts where the pronominal subject is not topical but nevertheless is mentioned for pragmatic purposes (Posio 2012:161-162). This last function, i.e. the backgrounding or de-focusing 
function of the postverbal position, may explain why the formal address pronoun usted often occurs postverbally: speakers tend to express it for politeness reasons even though it is not topical in situations where other personal pronouns would be left unexpressed (Fernández Soriano 1999:1235). Serrano and Aijón Oliva (2011:149) also consider postverbal pronominal subjects to be less agentive and salient than preverbal ones.

\section{Conclusions}

Due to the extensive research on subject pronoun use in Spanish, there is consensus on the effect of several factor groups on subject expression: grammatical person, referential continuity and priming have been shown to have a significant effect in all varieties studied so far, although the rates of expressed subjects vary considerably from one dialect to another. The frequency of verb forms in speech may also affect subject pronoun use through a mechanical entrenching effect, as argued by Erker and Guy (2012). While the general factors affecting subject pronoun expression are well understood and do not seem to differ significantly across dialects, it is less clear why different varieties of Spanish present different rates of subject pronoun expression and different rankings of the factor groups affecting it. Token-specific usage patterns affecting frequently occurring verbs constitute one potential site for cross-dialectal variation (Posio 2015) but do not account for all differences.

An interesting although little studied topic is the prosody of subject pronouns. In Spanish grammar, subject pronouns are considered to be always lexically stressed. Pešková (2015) offers a systematic prosodic analysis of subject pronouns in Buenos Aires Spanish. Her findings show that there is a clear phonological difference between focal and topical subject pronouns and that although subject pronouns carry lexical stress akin to nouns, they can easily become deaccented, for example in the postverbal final position in afterthoughts and right-dislocation. One might hypothesize that subject pronouns are more prone to loss of stress in dialects with more frequent subject expression rate such as Caribbean Spanish. However, to the best of my knowledge such hypotheses have not been tested in empirical studies.

Another research direction where few studies have been conducted to date is the historical evolution of pronominal subjects in Spanish, with the exception of Ramos (2016). Similarly, the expression of pronominal subjects in written texts has received considerably less attention than spoken discourse. 
While the existing body of research provides a basis for understanding variable subject expression in speech, the diachronic stages of subject expression require further investigation.

\section{References}

Aijón Oliva, Miguel Ángel \& Serrano, María José (2012). La posición del sujeto pronominal en las cláusulas no declarativas. Onomázein, 26(2), 131-164.

Alba, Orlando (2004). Cómo hablamos los dominicanos: un enfoque sociolingüístico. Santo Domingo: Grupo León Jiménez.

Alfaraz, Gabriela G. (2015). Variation of overt and null subject pronouns in the Spanish of Santo Domingo. In Carvalho, Ana María; Orozco, Rafael \& Shin, Naomi Lapidus (2015). Pp. 3-16.

Ariel, Mira (1994). Interpreting anaphoric expressions: a cognitive versus a pragmatic approach. Journal of Linguistics, 30, 3-42.

Bayley, Robert; Holland, Cory \& Ware, Kristen (2013). Lexical Frequency and Syntactic Variation: A Test of a Linguistic Hypothesis. University of Pennsylvania Working Papers in Linguistics, 19(2), 21-30.

Bayley, Robert \& Pease-Álvarez, Lucinda (1996). Null and expressed pronoun variation in Mexican-descent children’s Spanish. In Arnold, Jennifer; Blake, Renee \& Davidson, Brad (eds.), Sociolinguistic variation: Data, theory, and analysis. Stanford: Center for the Study of Language and Information, pp. 85-99.

Bentivoglio, Paola (1987). Los sujetos pronominales de primera persona en el habla de Caracas. Caracas: Universidad Central de Venezuela, Consejo de Desarrollo Científico y Humanístico.

Bock, J. K., \& Griffin, Z. M. (2000). The persistence of structural priming: transient activation or implicit learning?. Journal of Experimental Psychology, 129, 177-192.

Bullock, Barbara E. \& Toribio, Jacqueline Almeida (2007). Reconsidering Dominican Spanish: Data from the rural Cibao. Revista Internacional de Lingüística Iberoamericana, 7(2), 49-73.

Butt, John \& Benjamin, Carmen (2004). A New Reference Grammar of Modern Spanish. London: Arnold. 
Cameron, Richard \& Flores-Ferrán, Nydia (2004). Perseveration of subject expression across regional dialects of Spanish. Spanish in Context, 1(1), 41-65.

Cameron, Richard (1992). Pronominal and Null Subject Variation in Spanish: Constraints, Dialects, and Functional Compensation. Doctoral dissertation, University of Pennsylvania at Philadelphia.

Cameron, Richard (1994). Ambiguous agreement, functional compensation, and nonspecific tú in the Spanish of San Juan, Puerto Rico, and Madrid, Spain. Language Variation and Change, 5(3), 305-334.

Cameron, Richard (1995). The scope and limit of switch reference as a constraint on pronominal subject expression. Hispanic Linguistics 6/7, 1-27.

Cameron, Richard (1997). Accessibility theory in a variable syntax of Spanish. Journal of Pragmatics, 28, 29-67.

Carvalho, Ana M.; Orozco, Rafael \& Shin, Naomi Lapidus, Eds. (2015). Subject Pronoun Expression in Spanish. A Cross-Dialectal Perspective. Washington D.C: Georgetown University Press.

Chomsky, Noam (1981). Lectures on government and binding. Dordrecht: Foris.

CREA = REAL ACADEMIA ESPAÑOLA. Corpus de referencia del español actual. Available at: http://www.rae.es. Retrieved on December 15, 2016.

Davidson, Brad (1996). 'Pragmatic weight' and Spanish subject pronouns: the pragmatic and discourse uses of 'tú' and 'yo’ in spoken Madrid Spanish. Journal of Pragmatics, 26(4), 543-565.

de Prada Pérez, Ana (2015). First person singular subject pronoun expression in Spanish in contact with Catalan. In Carvalho, Ana María; Orozco, Rafael \& Shin, Naomi Lapidus (2015). Pp. 121142.

DeMello, George (2000). Tú impersonal en el habla culta. Nueva Revista de Filología Hispánica, 48(2), 359-372.

Dryer, Matthew S. (2011). Expression of pronominal subjects. In Dryer, Matthew S. \& Haspelmath, Martin (Eds.), The World Atlas of Language Structures Online. Munich: Max Planck Digital 
Library. Chapter 101. Available online at wals.info/chapter/101. Accessed on September 1, 2016.

Duarte, Maria Eugênia Lamoglia (2000). The loss of the avoid pronoun principle in Brazilian Portuguese. In Kato, M.A. \& Negrão, E.V. (Eds.), Brazilian Portuguese and the null subject parameter. Frankfurt am Main: Vervuert Verlag. Pp. 17-36.

Elinzaincín, Adolfo (1995). Personal pronouns for inanimate entities in Uruguayan Spanish in contact with Portuguese. In Silva-Corvalán, Carmen (Ed.), Spanish in four continents: studies in language contact and bilingualism. Washington DC: Georgetown University Press. Pp. 117-131.

Enríquez, Emilia V. (1984). El pronombre personal sujeto en la lengua española hablada en Madrid. Madrid: Instituto Miguel de Cervantes.

Erker, Daniel \& Guy, Gregory (2012). The role of lexical frequency in syntactic variability: variable subject personal pronoun expression in Spanish. Language 88(3), 526-557.

Fernández Soriano, Olga (1999). El pronombre personal. Formas y distribuciones. Pronombres átonos y tónicos. In Bosque, Ignacio \& Demonte, Violeta (Eds.), Gramática descriptiva de la lengua española. Volumen 1: Sintaxis básica de las clases de palabras. Madrid: Espasa Calpe. Pp. 1209-1273.

Flores-Ferrán, Nydia (2004). Spanish subject personal pronoun use in New York City Puerto Ricans: Can we rest the case of English contact? Language Variation and Change, 16, 49-73.

Geeslin, Kimberly \& Gudmestad, Aarnes (2016). Subject expression in Spanish. Contrasts between native and non-native speakers for first and second-person singular referents. Spanish in Context, 13(1), 53-79.

Geeslin, Kimberly; Linford, Bret \& Fafulas, Stephen (2015). Variable subject expression in second language Spanish In Carvalho, Ana María; Orozco, Rafael \& Shin, Naomi Lapidus (2015). Pp. 191-209.

Gili y Gaya, Samuel (1964). Curso superior de sintaxis española. Barcelona: Bibliograf.

Givón, Talmy (1983). Topic Continuity in Discourse: A Quantitative Cross Language Study. Typological Studies in Language 3. Amsterdam: John Benjamins.

Granda Gutierrez, G. de. (1972). Transculturación e interferencia lingüística en el Puerto Rico 
contemporáneo (1898-1968). Puerto Rico: Editorial Edil.

Guirado, Kristel (2011). La alternancia tú uno impersonal en el habla de Caracas. Revista de Lingüística, 26, 26-54.

Hochberg, Judith G. (1986). Functional compensation for /s/ deletion in Puerto Rican Spanish. Language, 62(3), 609-621.

Hurtado, Luz Marcela (2005). Condicionamientos sintáctico-semánticos de la expresión del sujeto en el español colombiano. Hispania, 88(2), 335-348.

Kluge, Bettina (2010). El uso de formas de tratamiento en las estrategias de generalización. In Hummel, M.; Kluge, B. \& Vázquez Laslop, M.E. (Eds.), Formas y fórmulas de tratamiento en el mundo hispánico. México D.F.: El Colegio de México, Graz: Karl-Franzens-Universität. Pp. 11071136.

Lastra, Yolanda \& Butragueño, Pedro Martín (2015). Subject pronoun expression in oral Mexican Spanish. In Carvalho, Ana María; Orozco, Rafael \& Shin, Naomi Lapidus (2015). Pp. 39-58.

Lapidus, Naomi \& Otheguy, Ricardo (2005). Overt nonspecific ellos in Spanish in New York. Spanish in Context, 2, 157-74.

Linford, Bret, Avizia Long, Megan Solon, Melissa Whatley \& Kimberly Geeslin. (2016a). Lexical frequency and subject expression in native and non-native Spanish: A closer look at independent and mediating effects. In F. Sessarego \& F. Tejedo (eds.), Spanish Language and Sociolinguistic Analysis. Issues in Hispanic and Lusophone Linguistics, 8. Philadelphia, PA: John Benjamins Publishing Company. Pp. 197-216.

Linford, Bret, Avizia Long, Megan Solon \& Kimberly Geeslin. (2016b). Measuring Lexical Frequency: Comparison Groups and Subject Expression in L2 Spanish. In L. Ortega, A. E. Tyler, H. I. Park \& M. Uno (eds.), The Usage-based Study of Language Learning and Multilingualism. Washington, D.C.: Georgetown University Press. Pp. 137-154.

Lipski, John M. (1996). Patterns of pronominal evolution in Cuban-American bilinguals. In Roca, Ana \& Jensen, John B. (Eds.), Spanish in contact: Issues in bilingualism. Somerville, MA: Cascadilla. Pp. 159-86.

Martínez-Sanz, Cristina (2011). Null and overt subjects in a variable system: The case of 
Dominican Spanish. PhD dissertation, University of Ottawa.

Matos Amaral, Patrícia \& Schwenter, Scott A. (2005). Contrast and the (non-)occurrence of subject pronouns. In Eddington, D. (Ed.), Selected Proceedings of the 7th Hispanic Linguistics Symposium. Somerville: Cascadilla. Pp. 116-127.

Meyer-Hermann, Reinhard (1990). Sobre algunas condiciones pragmáticas de la posición del sujeto en español. ELUA Estudios de Lingüística, 6, 73-88.

Michnowicz, Jim (2015). Subject pronoun expression in contact with Maya in Yucatan Spanish. In Carvalho, Ana María; Orozco, Rafael \& Shin, Naomi Lapidus (2015). Pp. 101-120.

Montrul, Silvina \& Sánchez-Walker, Noelia (2015). Subject expression in bilingual school-age children in the United States. In Carvalho, Ana María; Orozco, Rafael \& Shin, Naomi Lapidus (2015). Pp. 231-247.

Morales, Amparo (1989). Hacia un universal sintáctico del español del Caribe. El orden SVO. Anuario de Lingüística Hispánica, 5, 139-152.

Morales, Amparo (1997). La hipótesis funcional y la aparición de sujeto no nominal: el español de Puerto Rico. Hispania, 80, 153-165.

Orozco, Rafael \& Guy, Gregory (2008). El uso variable de los pronombres sujetos: ¿qué pasa en la costa Caribe colombiana? In Westmoreland, M. \& Thomas, J.A. (Eds.), Selected Proceedings of the Fourth Workshop on Spanish Sociolinguistics. Somerville, MA: Cascadilla. Pp. 70-80.

Orozco, Rafael (2015). Pronominal variation in Colombian Costeño Spanish. In Carvalho, Ana María; Orozco, Rafael \& Shin, Naomi Lapidus (2015). Pp.17-58.

Otheguy, Ricardo \& Zentella, Ana Celia (2012). Spanish in New York: Language contact, dialect, levelling, and structural continuity. Oxford: Oxford University Press.

Otheguy, Ricardo; Zentella, Ana Celia \& Livert, David (2007). Language and dialect contact in Spanish in New York: Toward the formation of a speech community. Language, 83(4), 770-802.

Pešková, Andrea (2015). Sujetos pronominales en el español porteño: Implicaciones pragmáticas en la interfaz sintáctico-fonológica. Beihefte zur Zeitschrift für romanische Philologie 394. Berlin: De Gruyter Mouton. 
Posio, Pekka (2011). Spanish subject pronoun usage and verb semantics revisited: First and second person singular subject pronouns and focusing of attention in spoken Peninsular Spanish. Journal of Pragmatics, 43(3), 777-798.

Posio, Pekka (2012). The functions of postverbal pronominal subjects in spoken Peninsular Spanish and European Portuguese. Studies in Hispanic and Lusophone Linguistics, 5(1), 149-190.

Posio, Pekka (2015). Subject pronoun usage in formulaic sequences: Evidence from Peninsular Spanish. In Carvalho, Ana María; Orozco, Rafael \& Shin, Naomi Lapidus (2015). Pp. 59-80.

Posio, Pekka (2016). You and we: Impersonal second person singular and other referential devices in Spanish sociolinguistic interviews. Journal of Pragmatics, 99, 1-16.

Ramos, Miguel (2016). Continuity and change. First person singular subject pronoun expression in earlier Spanish. Spanish in Context, 13(1), 103-127.

Ranson, Diana (1991). Person marking in the wake of /s/ deletion in Andalusian Spanish. Language Variation and Change, 3(2), 133-152.

Ranson, Diana (2009). Variable subject expression in Old and Middle French prose texts: The role of verbal ambiguity. Romance Quarterly, 56(1), 33-45.

Roberts, Ian \& Holmberg, Anders (2010). Introduction: Parameters in minimalist theory. In Biberauer, T.; Holmberg, A.; Roberts, I \& Sheehan, M. (Eds.), Parametric variation: Null subjects in minimalist theory, Cambridge \& New York: Cambridge University Press. Pp. 1-57.

Seo, Seunghyun (2001). The frequency of null subject in Russian, Polish, Czech, Bulgarian and Serbo-Croatian: An analysis according to morphosyntactic environments. Doctoral dissertation, Indiana University.

Serrano, María José (2013). Variación sociosituacional de la colocación del sujeto pronominal en textos conversacionales. Spanish in Context, 10(2), 261-283.

Serrano, María José \& Aijón Oliva, Miguel Ángel (2010). La posición variable del sujeto pronominal en relación con la cortesía interactiva. Pragmalingüística, 18, 170-204.

Serrano, María José \& Aijón Oliva, Miguel Ángel (2011). Syntactic variation and communicative style. Language Sciences, 33, 138-153. 
Shin, Naomi Lapidus \& Erker, Daniel (2015). The emergenge of structured variability in morphosyntax. In Carvalho, Ana María; Orozco, Rafael \& Shin, Naomi Lapidus (2015). Pp. 169189.

Shin, Naomi Lapidus \& Otheguy, Ricardo (2013). Social class and gender impacting change in bilingual settings: Spanish subject pronoun use in New York. Language in Society, 42, 429-452.

Silva-Corvalán, Carmen (1982). Subject expression and placement in Mexican-American Spanish. In Amaste, J. \& Olivares, E. (Eds.), Spanish in the United States: sociolinguistic aspects. New York: Cambridge University Press. Pp. 93-120.

Silva-Corvalán, Carmen (1997). Variación sintáctica en el discurso oral: problemas metodológicos. In Moreno Fernández, F. (Ed.), Trabajos de Sociolingüística Hispánica. Alcalá de Henares: University of Alcalá. Pp. 115-135.

Silva-Corvalán, Carmen (2001). Sociolingüística y pragmática del español. Georgetown University Press, Washington.

Thompson, Sandra A. \& Mulac, Anthony (1991). A quantitative perspective on the grammaticalization of epistemic parentheticals in English. In Closs Traugott, Elizabeth \& Heine, Bernd (Eds.), Approaches to grammaticalization. Amsterdam \& Philadelphia: John Benjamins. Pp. 313-339.

Toribio, A. Jacqueline. 2000. Setting parametric limits on dialectal variation in Spanish. Lingua, 110, 315-341.

Torres Cacoullos, Rena \& Travis, Catherine E. (2011). Using structural variability to evaluate convergence via code-switching. International Journal of Bilingualism, 15, 241-267.

Torres Cacoullos, Rena \& Travis, Catherine E. (2016). Two languages, one effect: Structural priming in spontaneous code-switching. Bilingualism: Language and Cognition, 19(4), 733-753.

Travis, Catherine E. \& Torres Cacoullos, Rena (2012). What do subject pronouns do in discourse? Cognitive, mechanical and constructional factors in variation. Cognitive Linguistics, 23(4), 711748.

Travis, Catherine E. (2007). Genre effects on subject expression in Spanish: Priming in narrative 
and conversation. Language Variation and Change, 19(2), 101-135.

\section{Biographical note}

Pekka Posio is an associate professor of Spanish at Stockholm University. His research interests include contrastive syntax and pragmatics, variable subject expression in Spanish and Portuguese, human impersonal constructions, and other ways of referring to human participants in spoken discourse. 